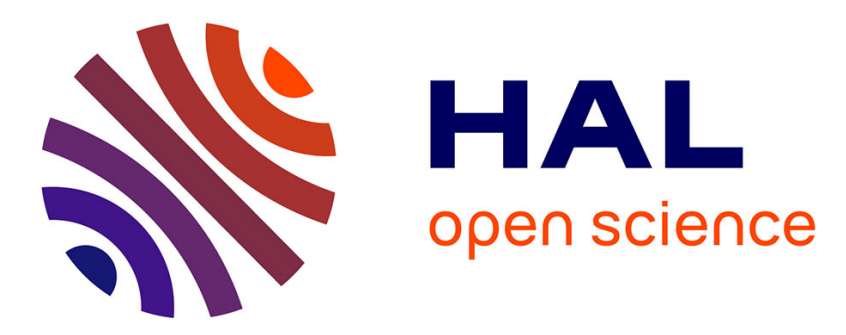

\title{
Bank funding constraints and the cost of capital of small firms
}

\author{
Oana Peia, Radu Vranceanu
}

\section{To cite this version:}

Oana Peia, Radu Vranceanu. Bank funding constraints and the cost of capital of small firms. 2015. hal-01109331

\section{HAL Id: hal-01109331 \\ https://essec.hal.science/hal-01109331}

Preprint submitted on 26 Jan 2015

HAL is a multi-disciplinary open access archive for the deposit and dissemination of scientific research documents, whether they are published or not. The documents may come from teaching and research institutions in France or abroad, or from public or private research centers.
L'archive ouverte pluridisciplinaire HAL, est destinée au dépôt et à la diffusion de documents scientifiques de niveau recherche, publiés ou non, émanant des établissements d'enseignement et de recherche français ou étrangers, des laboratoires publics ou privés. 


\title{
Bank funding constraints and the cost of capital of small firms
}

\author{
Research Center \\ ESSEC Working Paper 1501
}

2015

Oana Peia

Radu Vranceanu 


\title{
Bank funding constraints and the cost of capital of small firms *
}

\author{
Oana Peia ${ }^{\dagger} \quad$ Radu Vranceanu ${ }^{\ddagger}$
}

\begin{abstract}
This paper analyzes how banks' funding constraints impact the access and cost of capital of small firms. Banks raise external finance from a large number of small investors who face coordination problems and invest in small, risky businesses. When investors observe noisy signals about the true implementation cost of real sector projects, the model can be solved for a threshold equilibrium in the classical global games approach. We show that a "socially optimal" interest rate that maximizes the probability of success of the small firm is higher than the risk-free rate, because higher interest rates relax the bank's funding constraint. However, banks will generally set an interest rate higher than this socially optimal one. This gives rise to a built-in inefficiency of banking intermediation activity that can be corrected by various policy measures.
\end{abstract}

Keywords: Bank finance, Small business, Global games, Optimal return, Strategic uncertainty. JEL Classification index: D82, C72, G21, G32.

\footnotetext{
*Previous versions of this paper were circulated with the title "Optimal return in a model of bank small-business finance". We would like to thank Guillaume Chevillon, Gorkem Celik, Anastasios Dosis, Damien Besancenot, Asma Marouani and participants to the $3^{\text {rd }}$ European Conference on Banking and the Economy in Winchester, the $4^{\text {th }}$ International Conference of the Financial Engineering and Banking Society in Guildford and the $23^{\text {rd }}$ Annual Meeting of the European Financial Management Association in Rome, for their comments and suggestions. All remaining errors are ours.

${ }^{\dagger}$ ESSEC Business School and THEMA, 95021 Cergy, France. E-mail: oana.peia@essec.edu

*ESSEC Business School and THEMA, 95021 Cergy, France. E-mail: vranceanu@essec.fr
} 


\section{Introduction}

Traditional theories of small-business finance have primarily focused on the role of banks in overcoming the informational frictions that generally characterize small firms (Rajan, 1992). Yet, in their intermediation activity, banks perform a key role of channeling funds from those who save to the owners of new investment opportunities (Gorton and Winton, 2003). Small-business credit literature generally analyzes separately the relationship between banks and their providers of funds on the one hand, and banks and borrowers, on the other hand (Berger and Udell, 2002).

For instance, a large literature has analyzed the positive role of banks in increasing the access to credit of small businesses by engaging in close firm-creditor relationships (Petersen and Rajan, 1994; Berger and Udell, 1995; Degryse and Van Cayseele, 2000) 11 However, whether these lending relationships have a positive or negative effect on the cost of capital to firms is not clear 2 From a theoretical perspective, close bank-firm relationships should reduce the bank's cost of providing funds and, in competitive markets, these cost savings should be passed along to the borrower (Petersen and Rajan, 1994; Boot and Thakor, 1994). On the other hand, if the information acquired by the bank cannot be easily accessed by external investors, then the bank can acquire some form of "informational market power" that would result in higher interest rates (as in Greenbaum, Kanatas and Venezia, 1989; Sharpe, 1990; Rajan, 1992).

A more recent empirical literature, however, looks at banks' ability to raise funds themselves and how this impacts lending to the real economy. For example, Khwaja and Mian (2008) study a large liquidity shock to Pakistani banks and find that a one percent drop in bank liquidity resulted in a 0.87 percent drop in lending to small firms. Similarly, Paravisini (2008) shows how Argentinian local banks expand credit by $\$ 0.66$ in response to an additional dollar of external financing as a result of a government lending program to small businesses. This suggests that banks' funding constraints may represent an important reason for underinvestment in the small business sector. Evidence from the 2007-09 financial crisis presents a similar picture in developed economies (Santos, 2011; Iyer, Peydro, da Rocha-Lopes and Schoar, 2014).

A complete analysis of small-business bank finance should therefore study the interactions between the two sides of the market: banks and their creditors on the one side, and banks and firms, on the other. The main goal of this paper is to do so by developing a simple model of bank finance which emphasizes the importance of funding constraints for banks themselves and how these can affect the availability and cost of capital for small firms.

We model the interactions between a financial sector represented by a bank and its creditors and a real sector comprising of a small entrepreneurial firm. The firm owns a new risky technology and borrows from the bank to implement it. Technological risk is captured by a stochastic cost occurring during the implementation of the project. The firm's output is increasing in the amount of capital raised according to a linear technology, such that the probability that the firm makes a profit is increasing in the availability of capital. The capital available, on the other hand, depends on the number of investors

\footnotetext{
${ }^{1}$ These lending relationships refer to the bank's investment in acquiring "soft" information about the firm, such as the entrepreneur's talent, future prospects and business environment, often proprietary in nature and not easily accessible to outside investors (see Boot, 2000, for an overview).

${ }^{2}$ Looking at US data, Berger and Udell (1995) find that strong bank-borrower relationships are empirically associated with lower loan interest rates, whereas Petersen and Rajan (1994) find no statistically significant link. Taking evidence from European data, Degryse and Van Cayseele (2000) show that loan rates actually increase in the duration of the relationship, whereas Harhoff and Körting (1998) find no effect.
} 
who decide to place their funds in the banking sector. This brings about a typical coordination problem with strategic complementarity, as the probability of success of the project increases with the number of investors who fund the bank. Under perfect information this type of coordination problems generate multiple equilibria (Diamond and Dybvig, 1983). However, the assumption of perfect information is very strong, particularly when applied to small-business finance. If, instead, we assume that investors only observe a noisy signal about the true technological cost, the problem can be analyzed as a standard global game (Carlsson and Van Damme, 1993; Morris and Shin, 1998; Morris and Shin, 2001; Morris and Shin, 2004) 3 In this methodology, uncertainty about the informational structure of the game can eliminate the multiple equilibria, such that the coordination problem is characterized by a unique "threshold or switching" equilibrium. Our equilibrium solution builds on this established result $4^{4} \mathrm{We}$ show that investors' coordination problem presents a threshold equilibrium, where the firm's project succeeds if the technological cost is below a critical value, and fails otherwise.

The main contribution of the paper is to show that this critical threshold depends in a nonlinear way on the interest rate chosen by the bank. The impact of the return on capital on the critical cost is driven by two opposite effects. On the one hand, higher returns mitigate investors' coordination problem and make the decision to lend to the bank more appealing. This increases the amount of capital lent to the firm, and, implicitly, its probability of success. On the other hand, higher interest rates raise the cost of capital of the firm and have an adverse effect on its probability of success. We show that there exists a "socially optimal" interest rate that yields the highest chances of success of the entrepreneurial firm. This interest rate is higher than the risk-free rate and the spread between these returns is not necessarily driven by market power. Indeed, this result holds even if banks operate in a competitive, zero-profit environment. What this spread reflects is first and foremost the coordination failures among bank creditors. Taking the analysis one step further, we show that profit-maximizing banks will set an interest rate higher than the socially optimal one, a result that also holds for a highly competitive banking sector. This generates a form of credit market inefficiency which is the result of the way in which banks fund themselves. We highlight different policy measures that can mitigate these inefficiencies.

Our analysis shows how funding frictions in the banking sector can originate inefficiencies in the allocation of capital to the real sector. In a framework related to ours, Bebchuk and Goldstein (2011) model a credit-market freeze which arises from a coordination failure among banks to extend credit to operating firms. In their model, real sector projects are highly interdependent and, in this context, failure of some banks to lend leads all projects to collapse. They study how policy responses can get an economy out of a credit-market freeze. In our model, banks can mitigate coordination failures among investors through higher interest rates. This brings about, however, an inefficient shortage of credit in the economy: more capital could have been directed towards the real sector in the absence of such coordination problems. Generally, theories on credit rationing inefficiencies focus on borrower adverse selection problems (Stiglitz and Weiss, 1981; Sharpe, 1990; for a survey, see Jaffee and Stiglitz, 1990). Here, we show that banks' funding constraints can generate similar inefficiencies. A similar intuition

\footnotetext{
${ }^{3}$ The methodology has been applied to various economic problems involving coordination frictions, such as currency crises, bank runs, credit risk and illiquidity debt default (see, inter alia, Morris and Shin, 2001; Morris and Shin, 2004; Morris and Shin, 2009; Bebchuk and Goldstein, 2011).

${ }^{4}$ In most existing global games models the "fundamentals" of the economy are captured by a state variable related to the ability of the economy to cope with external shocks and has a rather "generic" nature. Here, the state variable can be related directly to the technological uncertainty specific to new investment projects.
} 
is present in Agur (2012; 2013) who shows how credit rationing can arise when banks fund themselves through secured wholesale bank finance.

Our work is also related to a growing literature on applied global games. In a related set-up, Li (2013) studies the systemic bankruptcy of firms with investment complementarities. She also highlights a non-monotonic relationship between lenders' expected profits and the interest rate, however in her model the coordination failure stems from real sector investment decisions.

The paper is organized as follows. The next section lays out the main assumptions. Section 3 presents the equilibrium solution, while Section 4 studies the relationship between returns and the equilibrium threshold. The question of how banks determine the optimal interest rate is addressed in Section 5. The last section concludes.

\section{Main assumptions}

The model is cast as a game between a continuum of small investors, a bank and a small entrepreneurial firm. Investors are the only agents endowed with wealth but, given the lack of appropriate financial instruments, they cannot invest directly in the firm.

\section{A. The firm}

We assume that the firm has no funds and needs to borrow from a bank to finance the project. It has access to a linear production technology with capital as the only variable input: $Y=(1+A) K$, where $K$ denotes capital and $A$ a positive parameter characteristic of the marginal product of capital $(1+A) 5^{5}$ The implementation of the firm's investment project is subject to technological uncertainty which we model as a stochastic fixed cost, denoted by $c$. This scale-invariant cost can be thought of as overhead costs specific to project implementation such as the need to comply with new safety, pollution or interoperability norms, as well as, additional design or research hours. For analytical convenience, we assume that this shock follows a normal distribution: $c \rightsquigarrow N\left(\bar{c}, \sigma^{2}\right)$, with a mean value $\bar{c}>0$ and a precision $\alpha=1 / \sigma^{2}{ }^{6}$ Given these assumptions, the (stochastic) profit of the firm is defined as the output less the payment to the bank, including interest and principal, and the stochastic fixed cost:

$$
\pi=(1+A) K-\left(1+R^{l}\right) K-c,
$$

where we denoted by $R^{l}$ the return required by the bank for the loan, with $R^{l} \leq A$.

\section{B. The Bank}

We represent a "modern" organization of banks that obtain external finance by attracting funds from investors and place these funds in real sector projects 7

\footnotetext{
${ }^{5}$ The main motivation for the choice of a linear technology is the finance gap hypothesis documented in empirical literature. This hypothesis suggests that small and medium-sized enterprises suffer from a shortage of external capital and that obtaining access to it is one of the biggest constraints to their growth and success (Beck, Demirgüç-Kunt and Maksimovic, 2008).

${ }^{6}$ Naturally, negative costs are of no interest for our analysis. Hence, we restrict our attention to the case in which the mean is sufficiently large and variance sufficiently small, such that $\operatorname{Pr}[c<0]$ is negligible.

${ }^{7}$ Thus, at difference with traditional bank models, in this set-up investors are directly exposed to the risk of the project. This assumption is much in line with the recent approach to bank regulation in Europe which places significant weight on the bail-in principle, according to which not only shareholders, but also bondholders and certain depositors are expected to incur losses should the bank face difficulties.
} 
In order to focus on the liabilities side of the bank, we model the lending relationship between the bank and the firm in a minimalist fashion. We assume that the bank, by acquiring knowledge about the firm's business environment or the entrepreneur, can obtain information about the worthiness of the project ${ }^{8}$ More precisely, the bank observes the true distribution of the technological shock that hits the firm's project and shares this information with (ex-ante uninformed) investors whose funds it seeks to attract.

Moreover, since our main objective rests in analyzing the financial intermediation process, we also adopt a simplified perspective on the industrial organization of the banking sector. We simply assume that, depending on the degree of competition among banks, they can charge a fee $\tau$ on each unit of capital lent to the firm, granted that the firm's projects is succesful. In a perfectly competitive environment $\tau$ will tend to zero, while for banks enjoying some form of market power, $\tau>0$. In other words, the mark-up $\tau$ is a parameter that captures the intensity of competition in the banking sector. If we denote by $R$ the interest the bank commits to pay to investors if the firm's project is successful, then $R^{l}=R+\tau$.

Thus, for a positive (even if small) $\tau$, the bank earns a mark-up for every unit of capital lent to the firm. Since the only constraint in lending to the real sector is the bank's ability to attract external funds from investors, the bank will set the interest rate, $R$, such as to attract as many funds as possible. This objective is tantamount to the maximization of the bank's total profits, which are represented by $\tau K$.

\section{Investors}

There is a continuum $n=1$ of risk-neutral investors, each endowed with one unit of wealth. They have the choice between placing their funds in the banking sector or investing in a safe asset which yields a return $r$. The return promised by the bank, $R$ is risky and depends on the success of the entrepreneurial firm. If the investment in the firm proves to be successful, investors receive $R \geq r>0$. However, if the firm fails, investors recover a liquidation value, $v<1$. We denote the proportion of investors who lend to the bank by $\ell$, with $\ell \in[0,1]$.

At the outset of the game investors are "uninformed" and they have no means of inferring the worthiness of the new project from public information. By entering in a contract with the bank, the latter shares with them information about the true distribution of the technological shock. At this moment the distribution of shocks $c \rightsquigarrow N(\bar{c}, 1 / \alpha)$ becomes common knowledge. Furthermore, we assume that once the shock is realized, each investor receives a private signal about the true value of $c$ :

$$
x_{i}=c+\varepsilon_{i},
$$

where the idiosyncratic bias $\varepsilon_{i}$ is also normally distributed among investors with zero mean and precision $\beta, \varepsilon \rightsquigarrow N(0,1 / \beta)$. One way to think of this private signal is that it represents each investors' private assessment about the true risk of the project. As a result, investors' payoff, contingent upon

\footnotetext{
${ }^{8}$ This ability of the bank to gauge the riskiness of the project resembles the relationship specific information bankers get in Sharpe (1990), Rajan (1992) and Diamond and Rajan (2001).
} 
their private beliefs, as well as the realization of the shock $c$, can be written as:

$$
U= \begin{cases}\text { lend to the bank } & \begin{cases}1+R & \text { if } \pi \geq 0 \\ v & \text { if } \pi<0\end{cases} \\ \text { invest in safe asset } & 1+r\end{cases}
$$

\section{Timing}

The sequence of decisions and the information structure of the game are depicted in Figure 1. At

\begin{tabular}{l|l|l}
\multicolumn{1}{c|}{$\mathrm{t}=0$} & \multicolumn{1}{c|}{$\mathrm{t}=1$} & \multicolumn{1}{c}{$\mathrm{t}=2$} \\
\hline $\begin{array}{l}\text { The firm and the } \\
\text { bank enter the } \\
\text { credit relationship }\end{array}$ & $\begin{array}{l}\text { - Technological shock is realized } \\
\text { - Investors observe a noisy signal } \\
\text { about the technological shock }\end{array}$ & $\begin{array}{l}\text { Investors receive } 1+R \\
\text { if project is } \\
\text { successful and } v \\
\text { otherwise }\end{array}$ \\
& $\begin{array}{l}\text { Bank decides on } R \\
\text { Investors decide on lending to } \\
\text { the bank or investing in the safe } \\
\text { asset }\end{array}$ & $\begin{array}{l}\text { The bank transfers capital to the } \\
\text { firm }\end{array}$
\end{tabular}

Figure 1: Timing

time $t=0$, the firm and the bank enter the credit relationship. The bank observes the distribution of technological shocks and shares the information with investors. It sets the interest rate $R$. In $t=1$, the technological shock is realized. Investors observe a noisy signal. They decide whether to lend their funds to the bank, based on the signals they receive and the return $R$ promised by the bank. The supply of funds for the project is thus equal to the number of investors, $\ell$, who choose the participation strategy. At time $t=2$, if the firm makes a positive profit, it pays $R^{l}$ to the bank, otherwise the firm is liquidated and investors get the residual value $v$.

\section{The Equilibrium}

Given the firm's production technology in Equation (11), its demand for funds is infinitely elastic. Thus, the equilibrium capital is given by the supply of funds: $K=\ell$ and the firm's profit function can be rewritten as:

$$
\pi=(A-\tau-R) \ell-c .
$$

Equation (3) points out the importance of coordination among investors. When the cost is zero (or below), the project succeeds even if only one investor participates. However, for a sufficiently high shock, when $c>(A-\tau-R)$, the firm fails (makes negative profits) even if all investors $(\ell=1)$ participate. When $c$ lies in the interval $(0, A-\tau-R)$, the firm succeeds only if a critical mass of investors coordinate and lend to the bank. This brings about a coordination problem in which an investor's decision to lend to the bank depends on his belief about the beliefs of the others.

Such coordination games generate multiple equilibria under perfect information $9^{9}$ However, under

\footnotetext{
${ }^{9}$ If the technological cost is not too high, there is a high-risk, Pareto-dominant equilibrium, characterized by all investors lending to the bank. However, regardless of the size of the cost, there is also a zero-risk Pareto-dominated equilibrium in which no investor participates and the project fails.
} 
imperfect information the coordination game has been shown to exhibit a unique equilibrium (Carlsson and Van Damme, 1993). Morris and Shin (1998; 2001; 2004) propose an elegant equilibrium concept that applies to $n$-player coordination games with noisy signals. We do not repeat here the formal proof of their argument. The intuition behind their proof is that the signals, $x_{i}$, that investors receive convey information not only about the technological $\operatorname{cost} c$, but also about the signals that other investors receive. At the extreme, when $c=0$, an investor should lend no matter what the others do. Consider now an investor receiving a signal sightly above zero. This investor infers that other investors might have received signals equal to or below zero, and thus have a dominant strategy to lend. Then it is also optimal for him to lend as well. Applying the same logic several times, one can establish a boundary well above zero below which investors should lend. At the same time, investors have a dominant action not to lend whenever $c>(A-\tau-R)$, because projects fail even if every investor participates. So when an investor receives a signal slightly below $(A-\tau-R)$ he is pessimistic about the probability of success of the firm and prefers not to lend. Again, we can apply a backward reasoning and establish a boundary well below $(A-\tau-R)$ above which investors do not lend. Morris and Shin (2004) show that these two boundaries coincide, such that the coordination problem admits a unique equilibrium characterized by a "switching strategy" (invest / do not invest) around a "critical signal" (for a formal mathematical proof, see Morris and Shin, 2004). The equilibrium of the game is thus characterized by two thresholds, a "critical signal", which we will denote by $x^{*}$, which drives investors' switching strategy to invest or not, and a "cut-off cost", $c^{*}$, for which the firm's project is on the edge between failing or not. Proposition 1 states our basic equilibrium result.

PROPOSITION 1. Investors' coordination problem presents an unique equilibrium provided that the precision of the signal is large enough, more precisely if $\frac{\alpha}{\sqrt{\beta}} \leq \frac{\sqrt{2 \pi}}{A-\tau-R}$. The equilibrium critical cost, below which the firm's project succeeds, is implicitly defined by the following equation:

$$
c^{*}=(A-\tau-R) \Phi\left(\frac{\alpha}{\sqrt{\beta}}\left[c^{*}-\bar{c}-\frac{\sqrt{\alpha+\beta}}{\alpha} \Phi^{-1}\left(\frac{1+r-v}{1+R-v}\right)\right]\right),
$$

where $\Phi(\cdot)$ is the c.d.f. of the standard normal distribution.

PROOF. Following standard resolution steps (Morris and Shin, 2001, 2004), the two thresholds, $x^{*}$ and $c^{*}$ can be determined as the solution to a system of two equations.

First, when Nature draws a cost $c$, the proportion of investors who lend is equal to the frequency of investors who receive a signal below the critical signal, $x^{*}$ :

$$
\ell=\operatorname{Pr}\left(x_{i}<x^{*} \mid c\right)=\operatorname{Pr}\left(\varepsilon_{i}<x^{*}-c\right)=\Phi\left(\sqrt{\beta}\left(x^{*}-c\right)\right) .
$$

The cut-off cost, $c^{*}$, for which the firm is on the edge between failing and succeeding is: $c^{*}=(A-\tau-$ $R) \ell$. Thus, given Equation (5), $c^{*}$ is implicitly defined by:

$$
c^{*}=(A-\tau-R) \Phi\left(\sqrt{\beta}\left(x^{*}-c^{*}\right)\right) .
$$

This gives us the first equation which defines $c^{*}$ as a function of $x^{*}$.

Second, given our assumptions about the normality of the distributions of costs and signals, when 
an investor $i$ receives a signal $x_{i}$, his posterior distribution of $c$ is also normal, with mean $\left(\frac{\alpha \bar{c}+\beta x_{i}}{\alpha+\beta}\right)$ and precision $(\alpha+\beta)$. So, for an investor with signal $x_{i}$, the probability of failure of the firm is:

$$
\operatorname{Pr}\left(c>c^{*} \mid x_{i}\right)=1-\Phi\left(\sqrt{\alpha+\beta}\left[c^{*}-\frac{\alpha \bar{c}+\beta x_{i}}{\alpha+\beta}\right]\right) .
$$

Moreover, at the switching point, an investor receiving the critical signal $x^{*}$ is indifferent between lending or not to the bank. His indifference condition can be written as:

$$
(1+R)\left[1-\operatorname{Pr}\left(c>c^{*} \mid x^{*}\right)\right]+v \operatorname{Pr}\left(c>c^{*} \mid x^{*}\right)=(1+r),
$$

which is equivalent to:

$$
\Phi\left(\sqrt{\alpha+\beta}\left[c^{*}-\frac{\alpha \bar{c}+\beta x^{*}}{\alpha+\beta}\right]\right)=\frac{1+r-v}{1+R-v} .
$$

After some calculations it follows that:

$$
x^{*}-c^{*}=\frac{\alpha}{\beta}\left(c^{*}-\bar{c}\right)-\frac{\sqrt{\alpha+\beta}}{\beta} \Phi^{-1}\left(\frac{1+r-v}{1+R-v}\right),
$$

which defines $x^{*}$ as a function of $c^{*}$.

The equilibrium critical thresholds $x^{*}$ and $c^{*}$ are thus the solution to the system of Equations (6) and (10). By substituting Equation (10) in (6), we obtain the equation in Proposition 1:

$$
c^{*}=(A-\tau-R) \Phi\left(\frac{\alpha}{\sqrt{\beta}}\left[c^{*}-\bar{c}-\frac{\sqrt{\alpha+\beta}}{\alpha} \Phi^{-1}\left(\frac{1+r-v}{1+R-v}\right)\right]\right) .
$$

Graphically, the equilibrium cut-off cost is obtained at the intersection of the $45^{\circ}$ line and the scaled-up cumulative normal distribution with mean $\left[\bar{c}+\frac{\sqrt{\alpha+\beta}}{\alpha} \Phi^{-1}\left(\frac{1+r-v}{1+R-v}\right)\right]$ and standard deviation $\frac{\alpha}{\sqrt{\beta}}$ (see Figure 22. The uniqueness of this solution is guaranteed when the slope of the right hand-side of Equation $(11)$ is less than one, that is: $(A-\tau-R) \varphi(\cdot) \frac{\alpha}{\sqrt{\beta}}<1$, where $\varphi(\cdot)$ is the p.d.f. of the standard normal distribution. Given that $\varphi(\cdot) \leq \frac{1}{\sqrt{2 \pi}}$, then the unique solution exists if condition $\frac{\alpha}{\sqrt{\beta}} \leq \frac{\sqrt{2 \pi}}{A-\tau-R}$ holds. Q.E.D.

Clearly, there exists a range of costs for which viable projects fail due to lack of coordination among investors. In particular, for $c \in\left(c^{*}, A-\tau-R\right)$, the firm's project would succeed if all investors coordinate and lend to the bank (but they do not). This gives rise to a form of "inefficient credit allocation" which is the consequence of strategic uncertainty among investors.

The uniqueness of the equilibrium allows us to analyze in a straightforward way how the cutoff cost responds to changes in the parameters of our model. At the same time, changes in $c^{*}$ are tantamount to changes in the probability of success of the project, since $\operatorname{Pr}\left[c<c^{*}\right]=\Phi\left(\sqrt{\alpha}\left(c^{*}-\bar{c}\right)\right)$ is monotonously increasing in $c^{*}$. We derive all comparative statics in the Appendix.

A lower risk-free rate, $r$, prompts more investors to participate, and thus raises the probability of success of the firm. This might correspond to a situation where the key interest rate of monetary policy 


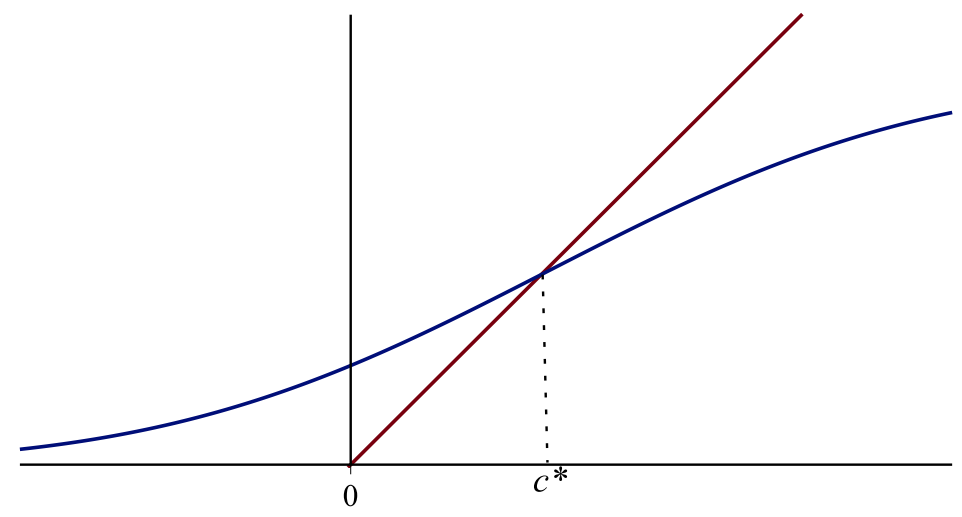

Figure 2: The equilibrium critical cost

is decreased in response to adverse macroeconomic shocks; in our model, this would induce more bank lending to the real sector. A similar effect is brought about by a smaller average technological cost faced by the firm, $\bar{c}$. This would happen in a period of radical innovations (such as the IT revolution in the late nineties). A closer lending relationship, which translates into the ability of the bank to secure a higher liquidation value, $v$, also increases the firm's access to finance. Notice that a very favorable macroeconomic environment can have an ambiguous effect on the success probability. Indeed, in such a context, the average cost $\bar{c}$ might decline, while, at the same time, the central bank would increase the key policy rate $r$. An increasing wedge $\tau$, as a result of an increasing concentration in the banking sector, leads to a decline in $c^{*}$, thus a decrease in the probability of success of the firm's project.

Finally, a key determinant of the equilibrium cut-off cost is the return $R$ chosen by the bank. We turn to this relationship next.

\section{The relationship between interest rates and the equilibrium cut-off cost}

Intuitively, the relationship between $c^{*}$ (and hence the probability of success of the firm) and $R$ is driven by two opposite effects. On the one hand, a higher return $R$ should facilitate investors' coordination and increase the proportion, $\ell$, who lend to the bank. This would, in turn, increase the chances that the project succeeds. On the other hand, a higher $R$ raises the interest burden of the small firm, $R+\tau$, which increases its probability of default. We can state the following result:

PROPOSITION 2. The equilibrium cut-off $\operatorname{cost} c^{*}(R)$ admits at least one maximum for $R$ in the interval $[r, A-\tau]$.

PROOF. First, from Equation (4), it is straightforward that, for $R \in[r, A-\tau]$, the function $c^{*}(R)$ is continuous, positive and lower than $(A-R-\tau)$. Moreover, at the extremes, we have $\lim _{R \rightarrow r} c^{*}=0$ and 
$\lim _{R \rightarrow A-\tau} c^{*}=04^{10}$ Then, applying the implicit function theorem to Equation 4 (see Appendix), we get:

$$
\frac{d c^{*}}{d R}=\frac{\sqrt{\frac{\alpha+\beta}{\beta}} \frac{(1+r-v)(A-\tau-R)}{(1+R-v)^{2}} \frac{\varphi(H)}{\varphi\left(\Phi^{-1}\left(\frac{1+r-v}{1+R-v}\right)\right)}-\Phi(H)}{1-(A-\tau-R) \frac{\alpha}{\sqrt{\beta}} \varphi(H)},
$$

where $H=\frac{\alpha}{\sqrt{\beta}}\left[c^{*}-\bar{c}-\frac{\sqrt{\alpha+\beta}}{\alpha} \Phi^{-1}\left(\frac{1+r-v}{1+R-v}\right)\right]$. In Equation 12$)$, we can check that $\left[\frac{d c^{*}}{d R}\right]_{R=A-\tau}<0$. Indeed, the denominator of expression $\sqrt{12} 2)$ is always positive since $1-(A-\tau-R) \frac{\alpha}{\sqrt{\beta}} \phi(\cdot) \geq 1-(A-$ $R-\tau) \frac{\alpha}{\sqrt{\beta}} \frac{1}{\sqrt{2 \pi}}>0$, given the uniqueness condition $\frac{\alpha}{\sqrt{\beta}} \leq \frac{\sqrt{2 \pi}}{A-\tau-R}$. The sign of the derivative is thus the sign of $-\Phi(\cdot)$ and for $R=A-\tau$, we have $\Phi(\cdot)>0$. This suffices to prove that $c^{*}(R)$ admits at least one maximum on the interval $[r, A-\tau]$. Q.E.D.

We denote the return that maximizes $c^{*}$ by $R_{f}$, since this interest rate also maximizes the probability of success of the firm. Since $\lim _{R \rightarrow r} c^{*}=0, R_{f}$ is necessarily higher than the risk-free rate $r$. This result holds even zero-profit competitive environment in which $\tau=0$ and is a consequence of investors' coordination problem. Thus, even in perfectly competitive banking sectors, small firms' cost of capital cannot be pushed down to the cost of funds if banks face funding constraints of their own.

To bring additional intuition to this result, Figure 3 uses a numerical simulation to represent the critical cost $c^{*}$ as a function of $R$. Parameter values are $c \sim N\left(0.1, \frac{1}{10}\right), \varepsilon \sim N\left(0, \frac{1}{100}\right), r=0.1, A=$ $0.5, v=0.1$ and $\tau=0.1$. The function $c^{*}(R)$ has an inverse $U$-shape 11 The highest $c^{*}$ is obtained for $R_{f}=0.19$. For this interest rate, the equilibrium critical cost below which the firm succeeds, is $c^{*}(0.19)=0.03$.

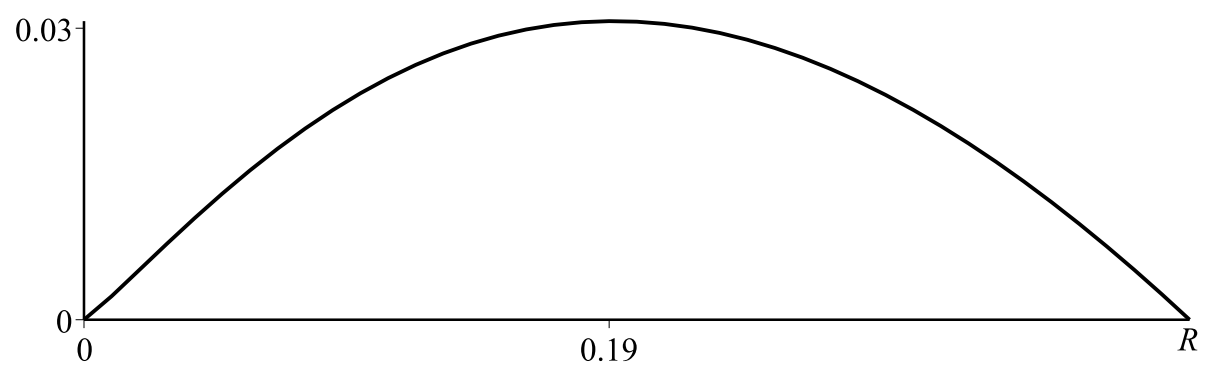

Figure 3: Evolution of threshold equilibrium $c^{*}$ as a function of $\mathrm{R}$

Our main result becomes even sharper in a special case of the game in which private signals become infinitely precise, i.e. $\beta \rightarrow \infty$. Under this assumption the condition for uniqueness always holds and $x^{*}$ and $c^{*}$ will converge to the same value:

$$
c_{\beta \rightarrow \infty}^{*}=x_{\beta \rightarrow \infty}^{*}=(A-\tau-R) \Phi\left(-\Phi^{-1}\left(\frac{1+r-v}{1+R-v}\right)\right)=\frac{(A-\tau-R)(R-r)}{1+R-v} .
$$

${ }^{10}$ Since $\Phi^{-1}(1)=\infty$ and $\Phi(-\infty)=0$.

${ }^{11}$ We obtain this shape for a very wide range of parameters. The Maple program is available upon request. 
From the derivative:

$$
\frac{d c_{\beta \rightarrow \infty}^{*}}{d R}=\frac{(1+r-v)(1+A-\tau-v)}{(1+R-v)^{2}}-1
$$

we can infer that this function is concave, with $\frac{d\left(c_{\beta \rightarrow \infty}^{*}\right)^{2}}{d^{2} R}<0$. The maximum cut-off cost is obtained for a $R_{f}$ solving:

$$
1+R_{f}-v=\sqrt{(1+r-v)(1+A-\tau-v)} .
$$

Note that for small values of $\left(R_{f}-v\right),(r-v)$ and $(A-\tau-v)$ a log approximation yields a neat result: $R_{f} \approx 0.5(r+A-\tau)$.

\section{Bank optimal return and market efficiency}

In this section, we compare the return that maximizes the critical cost with the optimal interest rate set by the bank. The former return can be thought of as a "socially optimal" interest rate since it maximizes the probability of success of the small business sector. We have shown that this socially optimal return is higher than the risk-free rate, even in the case of perfectly competitive markets, because higher interest rates mitigate investors' coordination problem and increase lending to the firm. We will show next that, given the bank's organizational structure, the interest rate it chooses is higher than the socially optimal one.

We have argued that, given the mark-up $\tau$, the total profit of the bank is proportional to the total funds attracted from outside investors, $\Pi_{b}=\tau \ell$. However, the bank decides on the return $R$ at the outset of the game before the shock $c$ is realized. Thus, the bank's profits are a function of the actual proportion of investors who end up lending to the bank, which depends on the realization of $c: E\left[\Pi_{b}\right]=$ $\tau E\left[\ell\left(x^{*}, c\right)\right]$, where the number of investors, $\ell$, is defined in Equation (5), as a function of the critical signal and the realized shock $c$. Furthermore, from Equation 10 we have that $x^{*}(R)=\frac{\alpha+\beta}{\beta} c^{*}(R)-$ $\frac{\alpha}{\beta} \bar{c}-\frac{\sqrt{\alpha+\beta}}{\beta} \Phi^{-1}\left(\frac{1+r-v}{1+R-v}\right)$, where $c^{*}(R)$ is the equilibrium cutoff cost, as defined in Equation (11).

The decison problem of the bank is thus:

$$
\operatorname{Max}_{R} \tau E\left[\ell\left(x^{*}(R), c\right)\right]
$$

where the bank knows the ex-ante distribution of shocks $c$ and the equilibrium values of $c^{*}$ and $x^{*}$ given $R$. Whenever, $c<c^{*}$, there is a positive number of investors who lend to the bank depending on the realized shock $c$. For $c>c^{*}$ the firm's project fails and the profit of the bank is zero.

We can state that:

PROPOSITION 3. The optimal interest rate set by the bank, $R_{b}$, is higher than the socially optimal return that maximizes the probability of success of the firm, $R_{f}$.

PROOF. The maximization problem in Equation (16) yields the following first order condition:

$$
\tau \frac{d}{d R} \int_{-\infty}^{c^{*}(R)} \Phi\left[\sqrt{\beta}\left(x^{*}(R)-c\right)\right] d c=0
$$


Dividing by $\tau$ and applying Leibniz's Rule we obtain:

$$
\int_{-\infty}^{c^{*}(R)} \frac{\partial}{\partial R} \Phi\left[\sqrt{\beta}\left(x^{*}(R)-c\right)\right] d c+\frac{\partial c^{*}(R)}{\partial R} \Phi \sqrt{\beta}\left[\left(x^{*}(R)-c^{*}(R)\right)\right]=0
$$

Differentiating under the integral yields:

$$
\sqrt{\beta} \frac{\partial x^{*}(R)}{\partial R} \int_{-\infty}^{c^{*}(R)} \varphi\left[\sqrt{\beta}\left(x^{*}(R)-c\right)\right] d c+\frac{\partial c^{*}(R)}{\partial R} \Phi\left[\sqrt{\beta}\left(x^{*}(R)-c^{*}(R)\right)\right]=0
$$

Using the identity $\int_{-\infty}^{c^{*}(R)} \varphi\left[\sqrt{\beta}\left(x^{*}(R)-c\right)\right] d c=-\frac{1}{\sqrt{\beta}} \Phi\left[\sqrt{\beta}\left(x^{*}(R)-c^{*}(R)\right)\right]$, we obtain:

$$
\left(-\frac{\partial x^{*}(R)}{\partial R}+\frac{\partial c^{*}(R)}{\partial R}\right) \Phi\left[\sqrt{\beta}\left(x^{*}(R)-c^{*}(R)\right)\right]=0
$$

Given that $\Phi(\cdot)>0$, the optimal $R_{b}$ must verify the condition: $\frac{\partial x^{*}(R)}{\partial R}=\frac{\partial c^{*}(R)}{\partial R}$. Thus, we obtain that:

$$
\frac{\partial c^{*}(R)}{\partial R}=-\frac{\sqrt{\alpha+\beta}}{\alpha} \frac{1}{\varphi\left(\Phi^{-1}\left(\frac{1+r-v}{1+R-v}\right)\right)} \frac{1+r-v}{(1+R-v)^{2}}<0
$$

In the proof of Proposition 2, we have shown that there exists a return $R_{f}$ that maximizes $c^{*}(R)$, i.e. $\left[\frac{d c^{*}}{d R}\right]_{R=R_{f}}=0$. From condition 190 above it follows that the optimal interest rate set by the bank, $R_{b}$, is reached on the downward slope of the curve $c^{*}(R)$, since $\left[\frac{d c^{*}}{d R}\right]_{R=R_{b}}<0$. Thus, this interest rate is necessarily higher than the one that maximizes the firm's probability of success $\left(R_{f}<R_{b}\right)$ and, as a result, higher than the risk-free rate.

$Q E D$.

Figure 4 displays the two curves and maxima in Propositions 2 and 3. The full line represents the evolution of the threshold equilibrium $\operatorname{cost} c^{*}$ as a function of $R$ using the same parameter values as in Figure 3 The dashed line shows the evolution of the total funds attracted by the bank, $\ell\left(c^{*}(R)\right)$ as a function of $R$, with the peak at $R_{b}=0.24$, which is the optimal return set by the bank. The maximum probability of success of the firm is $41.33 \%$; it is reached when $R_{f}=19 \%$. Consequently, under the return set by the bank, this probability drops to $41.09 \%$.

As mentioned, the parameter $\tau$ captures the intensity of competition in the banking sector. However, note that the result in Proposition 3 holds even in the case of a highly competitive banking sector, when $\tau$ is very close to zero. The higher return set by the bank is thus, not necessarily a consequence of market power, but of the manner in which the bank funds itself. One interesting case is the limit of perfect competition, where $\tau=0$. In this case, alternative bank objective functions can be considered. For example, in Diamond and Dybvig (1983) perfectly competitive banks provide liquidity insurance to depositors by maximizing their expected returns. We explore a similar problem in Appendix B, where we show that the interest rate which would maximize investors' expected return is still higher than the socially optimal one.

We can summarize our main findings as follows:

1. If coordination risk is ruled out, for instance if the bank could obtain finance from a single risk-neutral investor, the probability that the firm succeeds (makes a positive profit) will be just $\operatorname{Pr}[c<(A-\tau-R)]$ (given Equation 3). Obviously, this probability is maximized when the return 


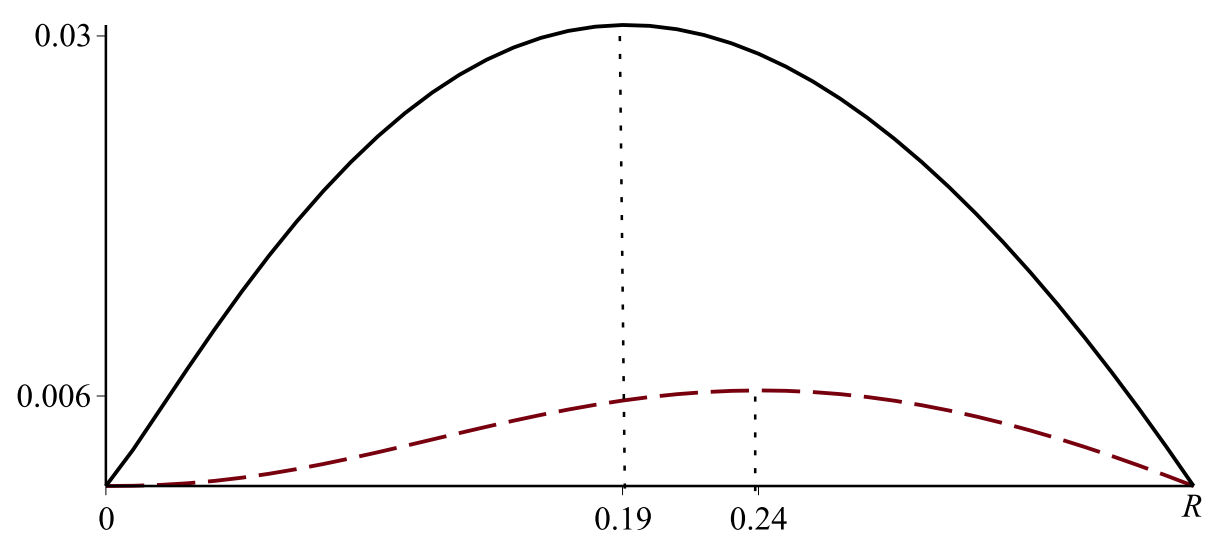

Figure 4: Social versus bank optimal return

$R$ takes its minimum value, i.e. $R=r$.

2. In the presence of coordination risk, the socially optimal interest rate that maximizes the probability of success of the firm is higher than the risk-free rate, $R_{f}>r$. Such high interest rates are not necessarily the consequence of banks abusing of some form of market power, since our results hold even in the case of perfectly competitive markets. Higher interest rates stem from the funding constraints of the bank and can, in fact, be beneficial to the firm, as they mitigate the coordination problem among investors and increase lending.

3. The bank's optimal interest rate is higher than the socially optimal one and is associated with a lower probability of success of the firm. This highlights a form of credit market inefficiency, which cannot be eliminated by reducing competition among banks.

This inefficiency of the financial intermediation market yields several policy implications. Our model suggests that banks' liquidity conditions, i.e. their ability to raise outside finance, is closely related to their loan pricing and availability of credit to small firms. The severity of these liquidity shortages is likely to be harsher during economic downturns. For example, empirical findings show that, during the 2007-2009 financial crisis, firms borrowing from constrained banks paid higher loan spreads (Santos, 2011) and that the contractions in credit supply were significantly higher for small firms (Iyer et al., 2014). Thus, reducing banks' funding constraints during crisis periods could improve the availability and cost of credit to small firms. This issue is particularly important in Europe where small firms are the lifeblood of the economy and where there is, currently, a deep wedge between SMEs' borrowing cost: 12 Our simple theoretical model provides an explanation for this wedge and calls for policy intervention that can relax small banks' funding constraints.

Government lending programs that make financing available to financial intermediaries with the requirement that these funds have to be lent to a particular group of borrowers are one example of such policies. Paravisini (2008) shows that the Credit Program to Small and Medium-Sized Firms implemented in Argentina between 1993 and 1999 has eased local banks' funding conditions and

\footnotetext{
${ }^{12}$ See The Economist, August 2014 "Don't bank on the banks".
} 
resulted in an increased lending to SMEs. Recent similar programs, such as the ECB's 2014 Targeted Longer-Term Refinancing Operations (TLTROs) have been introduced to revive credit, in particular to the small business sector 13 Similar measures are government guarantee programs, such as the US Small Business Administration 7(a) Loan Program, which guarantees bank loans to small businesses or the European Commission's new generous state aid framework (SAM) that provides risk finance to SMEs up to 15 mil. euros to complement the recent "funding gap" of European SMEs. Such measures should increase the liquidation value of the firms' projects ( $v$ in our model), and would also result in both an increased access to finance, as well as, lower capital costs for small businesses.

\section{Conclusion}

Obtaining access to external capital is an important constraint to the growth of small, entrepreneurial firms (Beck and Demirguc-Kunt, 2006). Thus, understanding how banks can facilitate their access to finance and contribute to their development is an important issue. In this paper, we develop a simple model of bank lending that highlights how banks' funding constraints impact the cost and availability of external finance for small entrepreneurial firms. When banks need to raise external finance from many small investors, the possibility that these investors fail to coordinate brings about a strategic uncertainty that compounds its effect to the investment project's technological risk, which takes the form of a random fixed cost.

We analyze the equilibrium behavior of investors in a standard global games approach. We show that there exists an equilibrium critical cost which separates the failure and success states of the project. This cost depends in a non-linear way on the return on capital chosen by the bank. On the one hand, a higher return mitigates the coordination problem among investors, increasing the volume of available funds. On the other hand, a higher interest rate increases the firm's probability of default. We highlight a new trade-off between the price of capital and the availability of funds to small firms which is the result of the strategic uncertainty among owners of capital.

We then show that a social planner aiming to maximize the probability of survival of small-business sector projects, should not bid interest rates down to the risk-free rate, since a high loan rate relaxes the bank's funding constraint and increases lending to the real sector. On the other hand, banks maximizing their profits would set an interest rate higher than this socially optimal rate. This points out some specific form of allocative inefficiency, which cannot be ruled out by banking sector competition. As a consequence, there can be a role for Government or Central Bank programs that can offset this "strategic uncertainty" premium in banks' funding markets, by providing conditional credit line or guarantees to constrained banks in order to increase the availability of credit to small businesses.

\footnotetext{
${ }^{13}$ See: https://www.ecb.europa.eu/press/pressconf/2014/html/is140807.en.html
} 


\section{References}

Agur, I. (2012), 'Credit rationing when banks are funding constrained', North American Journal of Economics and Finance 23(2), 220-227.

Agur, I. (2013), 'Wholesale bank funding, capital requirements and credit rationing', Journal of Financial Stability 9(1), 38-45.

Bebchuk, L. A. and Goldstein, I. (2011), 'Self-fulfilling credit market freezes', Review of Financial Studies 24(11), 3519-3555.

Beck, T. and Demirguc-Kunt, A. (2006), 'Small and medium-size enterprises: Access to finance as a growth constraint', Journal of Banking \& Finance 30(11), 2931-2943.

Beck, T., Demirgüç-Kunt, A. and Maksimovic, V. (2008), 'Financing patterns around the world: Are small firms different?', Journal of Financial Economics 89(3), 467-487.

Berger, A. N. and Udell, G. F. (1995), 'Relationship lending and lines of credit in small firm finance', Journal of Business 68(3), 351-381.

Berger, A. N. and Udell, G. F. (2002), 'Small business credit availability and relationship lending: The importance of bank organisational structure', Economic Journal 112(477), F32-F53.

Boot, A. W. (2000), 'Relationship banking: What do we know?', Journal of Financial Intermediation 9(1), 7-25.

Boot, A. W. A. and Thakor, A. V. (1994), 'Moral hazard and secured lending in an infinitely repeated credit market game', International Economic Review 35(4), 899-920.

Carlsson, H. and Van Damme, E. (1993), 'Global games and equilibrium selection', Econometrica 61(5), 989-1018.

Degryse, H. and Van Cayseele, P. (2000), 'Relationship lending within a bank-based system: Evidence from european small business data', Journal of Financial Intermediation 9(1), 90-109.

Diamond, D. W. and Dybvig, P. H. (1983), 'Bank runs, deposit insurance, and liquidity', Journal of Political Economy 91(3), 401-419.

Diamond, D. W. and Rajan, R. G. (2001), 'Liquidity risk, liquidity creation, and financial fragility: A theory of banking', Journal of Political Economy 109(2), 287-327.

Gorton, G. and Winton, A. (2003), 'Financial intermediation', Handbook of the Economics of Finance 1, 431-552.

Greenbaum, S. I., Kanatas, G. and Venezia, I. (1989), 'Equilibrium loan pricing under the bank-client relationship', Journal of Banking \& Finance 13(2), 221-235.

Harhoff, D. and Körting, T. (1998), 'Lending relationships in Germany-empirical evidence from survey data', Journal of Banking \& Finance 22(10), 1317-1353.

Iyer, R., Peydro, J.-L., da Rocha-Lopes, S. and Schoar, A. (2014), 'Interbank liquidity crunch and the firm credit crunch: Evidence from the 2007-2009 crisis', Review of Financial Studies 27(1), 347372.

Jaffee, D. and Stiglitz, J. (1990), Credit rationing, in B. M. Friedman and F. H. Hahn, eds, 'Handbook of Monetary Economics', Vol. 2 of Handbook of Monetary Economics, Elsevier, chapter 16, pp. 837-888. 
Khwaja, A. I. and Mian, A. (2008), 'Tracing the impact of bank liquidity shocks: Evidence from an emerging market', American Economic Review 98(4), 1413-1442.

Li, M. (2013), 'Investment complementarities, coordination failure, and systemic bankruptcy', Oxford Economic Papers 65(4), 767-788.

Morris, S. and Shin, H. S. (1998), 'Unique equilibrium in a model of self-fulfilling currency attacks', American Economic Review 88(3), 587-597.

Morris, S. and Shin, H. S. (2001), 'Rethinking multiple equilibria in macroeconomic modeling', NBER Macroeconomics Annual 2000 15, 139-182.

Morris, S. and Shin, H. S. (2004), 'Coordination risk and the price of debt', European Economic Review 48(1), 133-153.

Morris, S. and Shin, H. S. (2009), Illiquidity component of credit risk, Technical report, working paper, Princeton University.

Paravisini, D. (2008), 'Local bank financial constraints and firm access to external finance', Journal of Finance 63(5), 2161-2193.

Petersen, M. A. and Rajan, R. G. (1994), 'The benefits of lending relationships: Evidence from small business data', Journal of Finance 49(1), 3-37.

Rajan, R. G. (1992), 'Insiders and outsiders: The choice between informed and arm's-length debt', Journal of Finance 47(4), 1367-1400.

Santos, J. A. C. (2011), 'Bank corporate loan pricing following the subprime crisis', Review of Financial Studies 24(6), 1916-1943.

Sharpe, S. A. (1990), 'Asymmetric information, bank lending, and implicit contracts: A stylized model of customer relationships', The Journal of Finance 45(4), 1069-1087.

Stiglitz, J. E. and Weiss, A. (1981), 'Credit rationing in markets with imperfect information', American Economic Review 45(4), 393-410. 


\section{Appendix}

\section{A Comparative statics}

In this Appendix, we analyze how the equilibrium cut-off cost $c^{*}$ varies with the model's parameters. This follows from applying the implicit function theorem to Equation (4). Consider the function:

$$
I\left(c^{*}, R, r, \bar{c}, v, \tau\right)=c^{*}-(A-\tau-R) \Phi\left(\frac{\alpha}{\sqrt{\beta}}\left[c^{*}-\bar{c}-\frac{\sqrt{\alpha+\beta}}{\alpha} \Phi^{-1}\left(\frac{1+r-v}{1+R-v}\right)\right]\right)=0
$$

We have that:

$$
\frac{\partial I}{\partial c^{*}}=1-(A-\tau-R) \frac{\alpha}{\sqrt{\beta}} \varphi(H) \geq 1-(A-R) \frac{\alpha}{\sqrt{\beta}} \frac{1}{\sqrt{2 \pi}}>0,
$$

given the imposed condition for equilibrium uniqueness $\frac{\alpha}{\sqrt{\beta}} \leq \frac{\sqrt{2 \pi}}{A-R}$, and

$$
\begin{aligned}
\frac{\partial I}{\partial R} & =\Phi(H)-(A-\tau-R) \varphi(H) \frac{\sqrt{\alpha+\beta}}{\sqrt{\beta}} \frac{1}{\varphi\left(\Phi^{-1}\left(\frac{1+r-v}{1+R-v}\right)\right)} \frac{1+r-v}{(1+R-v)^{2}} \\
\frac{\partial I}{\partial r} & =(A-\tau-R) \varphi(H) \frac{\sqrt{\alpha+\beta}}{\sqrt{\beta}} \frac{1}{\varphi\left(\Phi^{-1}\left(\frac{1+r-v}{1+R-v}\right)\right)} \frac{1}{1+R-v}>0 \\
\frac{\partial I}{\partial \bar{c}} & =(A-\tau-R) \varphi(H) \frac{\alpha}{\sqrt{\beta}}>0 \\
\frac{\partial I}{\partial v} & =(A-\tau-R) \varphi(H) \frac{\sqrt{\alpha+\beta}}{\sqrt{\beta}} \frac{1}{\varphi\left(\Phi^{-1}\left(\frac{1+r-v}{1+R-v}\right)\right)} \frac{r-R}{(1+R-v)^{2}}<0 \\
\frac{\partial I}{\partial \tau} & =\tau \Phi(H)>0,
\end{aligned}
$$

where $H=\frac{\alpha}{\sqrt{\beta}}\left[c^{*}-\bar{c}-\frac{\sqrt{\alpha+\beta}}{\alpha} \Phi^{-1}\left(\frac{1+r-v}{1+R-v}\right)\right]$. By the implicit function theorem:

$$
\begin{aligned}
\frac{d c^{*}}{d R} & =-\frac{\partial I / \partial R}{\partial I / \partial c^{*}} \\
\frac{d c^{*}}{d r} & =-\frac{\partial I / \partial r}{\partial I / \partial c^{*}}<0 \\
\frac{d c^{*}}{d \bar{c}} & =-\frac{\partial I / \partial \bar{c}}{\partial I / \partial c^{*}}<0 \\
\frac{d c^{*}}{d v} & =-\frac{\partial I / \partial v}{\partial I / \partial c^{*}}>0 \\
\frac{d c^{*}}{d \tau} & =-\frac{\partial I / \partial \tau}{\partial I / \partial c^{*}}<0 .
\end{aligned}
$$

\section{B Investors' optimal return}

Perfect competition in the banking sector would drive profits to zero; banks would thus set the interest rates on loans equal to the interest rate paid to its creditors, $R^{l}=R$. In this case, one plausible goal for 
banks is to compete for funds from investors by maximizing their expected return 14

$$
R_{i}=\underset{R}{\arg \max }\left\{\operatorname{Pr}\left[c<c^{*}(R)\right](1+R)+\left(1-\operatorname{Pr}\left[c<c^{*}(R)\right]\right) v\right\} .
$$

From the first order condition we can show that:

$$
\frac{d c^{*}}{d R}=-\frac{\Phi\left(\sqrt{\alpha}\left(c^{*}-\bar{c}\right)\right)}{\varphi\left(\sqrt{\alpha}\left(c^{*}-\bar{c}\right)\right)}(1+R-v)^{-1}<0 .
$$

Thus, similar to the proof of Proposition 3, we can show that the return $R_{i}$ that maximizes investors' expected return is necessarily higher than the socially optimal return that maximizes $c^{*}(R)$, i.e. $\left[\frac{d c^{*}}{d R}\right]_{R=R_{f}}=0$, since it falls on the downward slope of $c^{*}(R),\left[\frac{d c^{*}}{d R}\right]_{R=R_{b}}<0$.

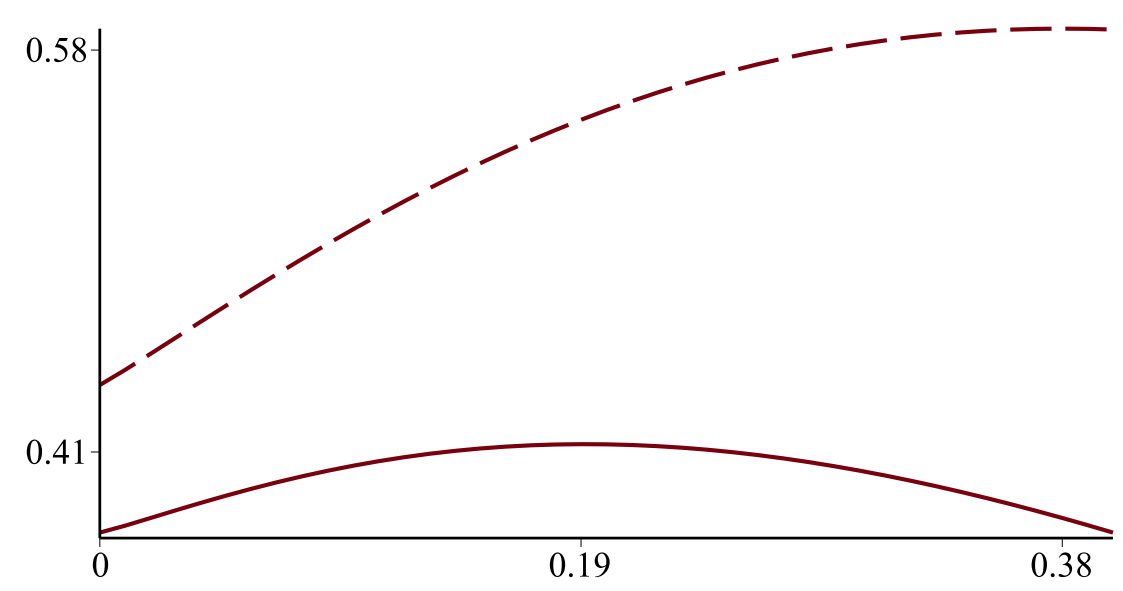

Figure 5: Investors' optimal return vs probability of success of the firm

We can also show in numerical simulations, that investors' expected return is also higher than the optimal return set by the bank. Figure 5 plots investors' expected return as a function of $R$ (dashed line) versus the probability of success of the firm. The interest rate that maximizes investors' expected return is well above $R_{f}=0.19$ or even $R_{b}=0.24$ and stands at $R_{i}=0.38$, which decreases the probability of success of the firm to $38 \%$.

\footnotetext{
${ }^{14} \mathrm{We}$ assumed that investors are risk neutral. Our main conclusion would also hold if investors were risk averse. Under this assumption, the optimal return that maximizes their expected utility would be even higher than the interest rate that maximizes expected returns.
} 
ESSEC Business School Avenue Bernard Hirsch BP 50105

95021 Cergy-Pontoise Cedex France

Tél. +33(0)134433000

$\mathrm{Fax}+33(0) 134433001$

www.essec fr

\section{ESSEC Executive Education} CNIT BP 230

92053 Paris-La Défense France

Tél. +33(0)146924900

Fax +33 (0)1 46924990

http://formation.essec.fr

ESSEC Business School

Singapore Campus

100 Victoria Street

National Library Building \# 13-02

Singapore 188064

essecasia@essec.fr

Tél. +6568849780

Fax +6568849781

www.essec.edu

Informations

+33 (0)134 433358

www.essec.fr

research.center@essec.fr

ISSN 1291-9616 